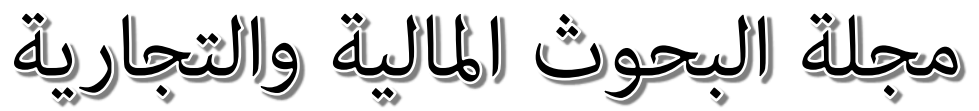

$$
\begin{aligned}
& \text { المجلد (21) - العدد الرابع - أكتوبر }
\end{aligned}
$$

\title{
The Effect of Company Specific Factors on the Profitability of Property \& Casualty Insurance industry in Egypt
}

\author{
Mahmoud Elsayed ${ }^{1}$ \\ Associate Professor \\ Insurance \& Actuarial Sciences Department \\ Faculty of Commerce - Cairo University
}

https://jsst.journals.ekb.eg/ رابط المجلة: 


\begin{abstract}
The aim of this study is to determine the factors that affect the financial performance of insurance market in Egypt. Return on Assets (ROA) and Return on Equity (ROE) were used as proxy for measuring financial performance. This study investigated the effects of company specific determinants such as: leverage, tangibility of assets, liquidity, company size, underwriting risk, and solvency margin on profitability by using multiple regression technique. Dependent variable was profitability measures, while independent variables were leverage, tangibility of assets, liquidity, underwriting risk, company size, and solvency margin. Secondary data obtained from the Financial Regulatory Authority (FRA) of insurance companies in Egypt were investigated as a panel data during the period from 2008 to 2017. The results illustrate that underwriting risk has insignificant effect on ROA, on the other hand, underwriting risk has significant effect on ROE. Liquidity has a negative effect on leverage and solvency margin. Also, there is a positive relationship between company size and ROA. Solvency margin has a positive significant effect on the profitability for Egyptian insurance market. In addition, the adverse and statistical relationship between solvency margin and leverage is important.
\end{abstract}

Keywords: Profitability, Property \& Casualty Insurance, Egypt

JEL classification: C23, G22, L25 


\section{Introduction}

Liquidity, solvency, and profitability are the most vital objectives of any company. Performance measurement is the most powerful tool to ensure the success of the strategy of insurance companies and puts managers and workers on the right track and ensure the implementation of all activities within the insurers and their resilience to competition. When the ownership of the firm is separated from the board of directors affects that financial Performance. The role of the performance measurement system is to help shareholders verify the management's commitment to achieving the objectives sought by the insurance.

This paper examines the factors that affect the profitability of the Egyptian non- life insurance companies. This study uses twenty-two Egyptian non-life insurance companies during the period from 2008 to 2017. The linear multiple regression analysis is used by considering (ROA and ROE) as a dependent variable. In contrast, independent variables are leverage, tangibility of assets, liquidity, underwriting risk, solvency margin, and company size.

The rest of our research is organized as follows: part two an overview of previous studies. Followed by part three the impact of company specific determinants on the Profitability, part four research methodology, part five application results and part six conclusion.

\section{Previous studies}

Aburime (2008) analyzed the factors of bank profitability in Nigeria, throughout 2000 to 2004. This study used the model of a panel data by consist of 91 observations of 33 banks. It concluded that there is a significant relation between the size of capital, the size of credit portfolio and the concentration of ownership and the portfolio of bank in Nigeria.

Ana-Maria and Batrinca (2014) analyzed the determinants of solvency in the Romanian insurance sector from 2008 to 2012. It concluded that the size, growth of written premium, equity, diversification, Investment ratio, retained risk ratio and solvency margin of the company have a significant positive relation on its solvency. On contrast, this study finds a negative relation between reinsurance dependence, underwriting risk and solvency of the firm. 
Athanasoglous, et al (2005) applied the model of a panel of Greek banks to decide the impact of bank-specific, industry-specific and macroeconomic factors of bank profitability from 1985 to 2001 . This paper found that capital has a significant impact on the bank profitability and the growth of labor productivity growth and profitability are positively related significantly, while operating expenses have a negative impact on the profitability. The relationship between the bank's ownership status and profitability is insignificant. Finally, the business cycle and profitability are significant positive only when output profitability is above its trend.

Charumathi (2012) reviewed the profitability factors of the life insurance companies during the period from 2008 to 2011 in India by using all 23 Indian life insurance companies as a sample. This study illustrated that there is a positive significant relation between the company size and liquidity on profitability. While, there is a negative significant relation between equity capital, leverage and premium growth on profitability. In addition the underwriting risk is independent with profitability.

Bilal, et al (2013) examined the factors of profitability in Pakistan's insurance market between 2006 and 2011.The sample of this research includes 31 insurers ( life and non-life insurers). It revealed that leverage, firm size, earning volatility and firm age are important factors of profitability whereas liquidity has no effect on the profitability.

Chen-Ying (2014) reviewed the determinants of profitability of the non-life insurance companies in Taiwan during the period from 1999 to 2001. This research applied two models (operating ratio and return on total assets). The results illustrated that the underwriting risk, reinsurance usage, financial holding group and return on investment are significantly related to the profitability in both these models. Also, economic growth rate is significantly related to the profitability according to the operating ratio model but insignificant according to the return on total assets model.

Daniel and Aemiro, (2013) applied the regression model for panel data of nine insurance companies from fourteen insurance firms in Ethiopia during the period 2005 to 2010 . This study concluded that there is a negative effect on the performance by leverage, company size and tangibility of assets. Furthermore, there is a negative impact on company's performance due to loss ratio and insurance premium growth. 
Hamadan (2008) investigated the effects of the firm specific factors such as the age, size, capital, loss ratio, and leverage on the profitability of the companies. The study concluded lauded that the firm age has no effect on its profitability. Also, there is a significant positive impact of the firm size on its profitability.

Hifza (2011) reviewed the impact of the firm specific factors that affect profitability such as the age, the size of the company, leverage ratio, loss ratio and the capital. Secondary data of Pakistan companies during the period from 2005 to 2009 obtained from the annual statistical books. This paper concluded that the age of the company has no effect on the performance. Whereas, there is a positive relation between company size and capital value on the performance.

Emine (2015) applied two ratios the first ratio technical profitability and the second ratio sales profitability ratio to measure the performance on twenty four non-life Turkish insurance companies during the period from 2006 to 2013. This paper concluded that the profitability is affected by company size, company age, loss ratio, current ratio, and premium growth.

Ana and Dusan (2016) Used Hausman test to decide whether fixed or random variable is used in regression technique. This paper analyzed the profitability of banking market in Serbia during the period from 2004 to 2011 by bank specific, market specific and macroeconomic determinants.

Eric et al (2013) this study explore the factors of the profitability of sixteen insurance companies in Ghana from 2005 to 2010. They found strong positive significant influence to leverage and liquidity on the profitability. While, apart from tangibility has a negative effect on profitability.

Shahid et al (2013) applied a multiple regression analysis to measure the profitability by using ROA of insurance market in Pakistan during the period from 2010 to 2013. This paper found that three aspects have a significant effect on the insurance market's profitability.

Teklit and Jasmindeep (2017) Used hausman test to determine whether to use fixed or random variable in regression technique. This study focused on fixed effect model a result of hausman test on seventeen Ethiopian insurers during the period from 2005 to 2015 to determine the factors that affect the profitability. This study concluded that have a significant impact on the profitability of insurers by company size, capital adequacy, liquidity, and 
Gross Domestic Product. On contrast, they found that had insignificant effect on profitability of insurance companies by leverage, loss ratio, market share and inflation rate.

Okparaka (2018) applied least square regression and measured the profitability by total premiums, total claims and total assets in Nigeria. This paper concluded that total premium, total claims and total assets have an insignificant impact on the profitability of insurers.

Kaukab and Nawaz (2019) examined the profitability by net profit ratio and return on assets. Moreover, company size measured by total sales and total assets. Panel data of ten listed companies on Pakistan stock exchange during the period from 2012 to 2016 . Correlation methods and regression analysis were conducted in the empirical analysis. The results concluded that no significant relation in case of textile companies in Pakistan. In addition to, total assets have a significant negative impact on the profitability.

Abeyrathna and Priyadarshana (2019) applied correlation analysis and regression analysis techniques to measure the profitability by firm size. Panel data of twenty listed companies on Sri Lanka stock exchange during the period from 2014 to 2017. This paper concluded that firm size has an insignificant impact on the profitability in Sri lanka.

Aster and Meseret (2019) applied ordinary least squire technique for panel data of nine insurance companies in Ethiopia to measure financial performance by ROA and ROE during the period from 2010 to 2015. This study concluded that capital adequacy, liquidity, size, age, loss, leverage were the main factors that have a significant impact on the profitability of insurers.

\section{Research Problem}

The market value of any firm depends on the financial performance as well as the economic growth; the profitability of the firm reflects the strength and the financial solvency. To do the insurance company is expected to determine the factors that affect the profitability of the firm. Afterwards, analyzing these factors to examine the financial performance of the insurance company. The lack of literature in the Egyptian insurance market on determining the profitability factors inspired the researcher to contribute on investigating the factors that impact the insurance market performance. 


\section{Research Importance}

Most of the previous researches interested in banks rather than insurance companies, also some studies focused on only financial efficiency analysis not on determinants that affect financial performance. Moreover, it is anticipated that this study will provide empirical results on profitability of Egyptian insurance companies that leads to promote the economy. In addition, Customers focused on understanding the ability of insurance companies to pay their obligations depending on the factors that affect the financial performance.

\section{Research Objectives}

The aim of this research is to identify that factors that determine the financial performance of the insurance company by:

- Identifying the key factors that affect the profitability.

- Determining the impact of these factors.

- Classifying the degree of each factor that affect the profitability.

- Determining the relation between these factors.

\section{Research Hypothesis}

Based on previous studies, our study adopt that Leverage, Tangibility of Assets, Liquidity, Underwriting Risk, Solvency Margin and Company Size with profitability are expected to influence firms' profitability as measured by (ROA) and (ROE). Accordingly, the following hypotheses were employed in this study:

First hypothesis: There is a significant positive relation between company size and profitability.

Second hypothesis: There is a significant negative relation between underwriting risk and profitability.

Third hypothesis: There is a significant negative relation between leverage and profitability.

Fourth hypothesis: There is a significant positive relation between solvency margin and profitability. 
Fifth hypothesis: there is significant negative relation between Tangibility of assets and profitability.

Sixth hypothesis: there is a significant negative relation between Liquidity and profitability.

\section{The Effect of Company Specific Factors on the Profitability}

In this study, The (ROA) measures the profitability where the (ROA) is measured by the net profit before tax over the total assets during a period by comparing net income to the average total assets.

The (ROE) also measures the profitability where the (ROE) is measured by the net profit before tax over equity during a period by comparing net income to the average equity. In other words, measures the profitability of a corporation in relation to stockholders' equity.

Internal variables are the factors that are often influenced by strategies $s$ and decisions of the insurers' management team. On the other hand, External variables are those that are beyond the control of management team in the insurance companies. The operational definitions of those variables are the following:

Leverage (LEV) is a measure of equity debt, high leverage is considered to be a firm with debts more than equity, and leverage is measured by total liabilities over total assets Moreover, there is a positive relation between risk and leverage.

Tangibility of Assets (TOA) is a measure of physical assets that consists of fixed assets and current assets, this measure is used for insurers operations, and Tangibility of Assets is measured by fixed assets over total assets. Insurers have predominantly tangible assets, which appears in their statement of financial position.

Liquidity (LIQ) refers to an insurer's ability to fulfill its short - term obligations. The ratio of current assets to current liabilities is commonly measured. Liquidity is measured by current liabilities over current assets. It also shows an insurer's ability to convert their assets as quickly as possible into cash. Low liquidity ratio indicates that it is difficult for an insurer to fulfill its short-term obligations. However, high liquidity ratio indicates that the insurer could generate income by investing in profitable areas. This 
makes the sign of liquidity ratio and profitability cannot be predicted, therefore further investigation is needed.

Underwriting Risk (UR) refers to the potential loss to an insurer as a result of inaccurate assessment of the risks associated with writing an insurance policies and changes in circumstances. Underwriting risk is measured by claims incurred over premiums earned. It includes pricing risk, reserve risk and reinsurance risk.

Solvency Margin (SM) is the amount of capital that is measured by net assets over net written premiums. Solvency margin must be sufficiently large to cover all the risks to which the concern is liable, within certain limits.

Company Size (SZE) is a measure that investigates the efficiency level according to total assets. Company size is measured by total assets.

Figure 1 Dependent Variable and Independent Variables

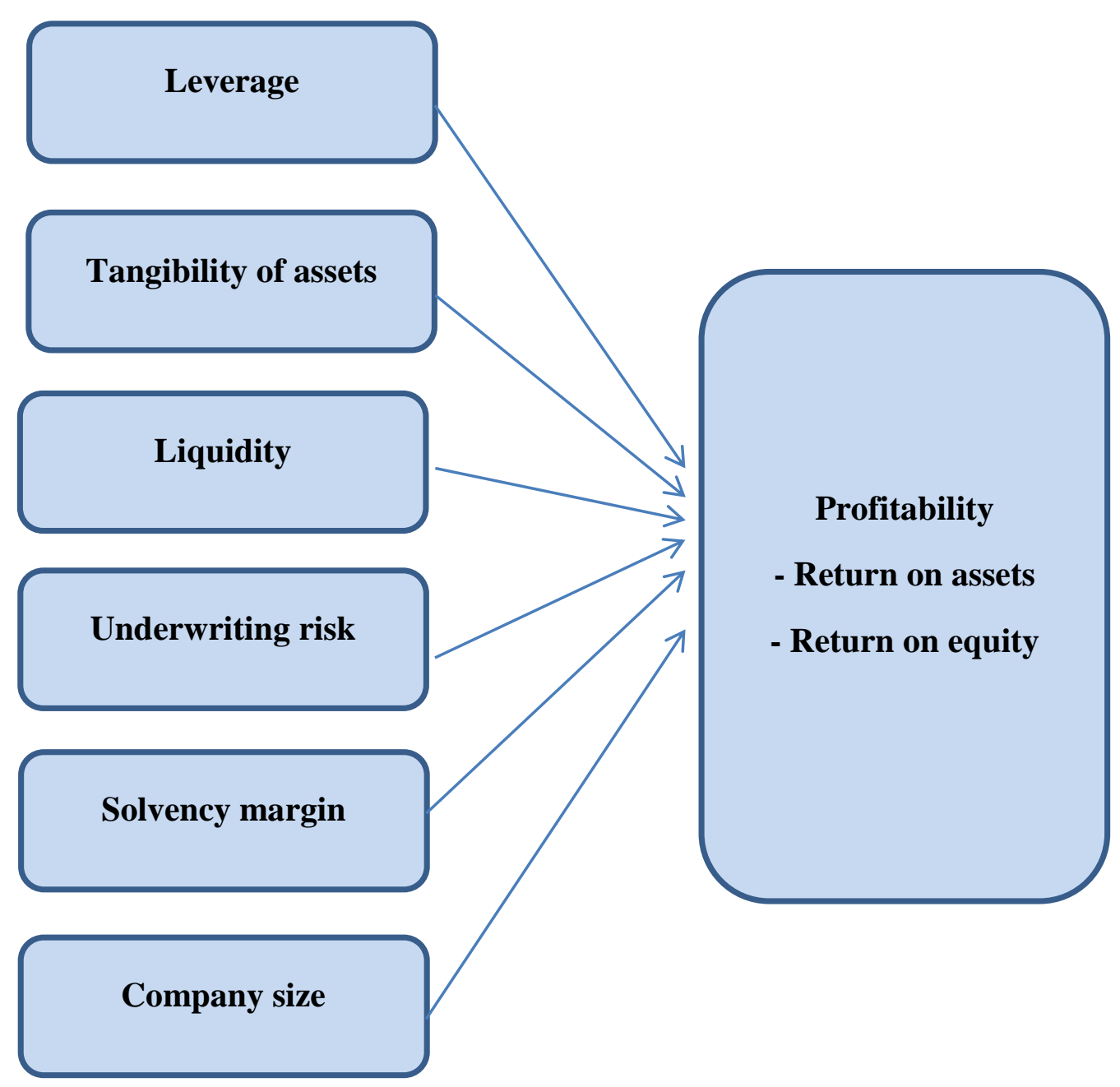




\section{Research methodology}

The basis of the approach of this research is the integration of the extrapolative approach and the method of development and the steps followed by research to achieve the objectives of the research is in two aspects

The first aspect represents the historical background of the variables dealt with the nature of the problem as well as the previous studies that dealt with the variables under study. The objective is to define the concept of each variable of the variables of the study to ensure that the variables are not misinterpreted either in the formulation stage of the research model or the stage of statistical analysis of data or stage interpretation of the results of statistical analysis

The second aspect is performing a field study by identifying the society and sample of the study represented in the insurance companies operating in the property insurance and liability within the Arab Republic of Egypt in the period of time from 2008 to 2017.

The sample size is 22 insurance companies working in property insurance and liability over the period 10 years and the method of data collection represented in reports containing consolidated budgets and detailed income data for the companies under study and the method of statistical analysis, which is represented in the model of multiple regression in addition to the analysis and discussion of the results of statistical analysis

This study contained all the 22 non-life Egyptian insurance companies .the study used secondary data drawn from the annual statistical books for the period from 2008 to 2017. This research uses the linear multiple regression analysis model using first model (Return on assets) as a dependent variable which is derived from dividing net profit before tax over the total assets, second model (Return on equity) as a dependent variable which is derived 
from dividing net profit before tax over the equity and company specific characteristics such as leverage, tangibility of assets, liquidity, underwriting risk, solvency margin and company size as an independent variable. Table 1 illustrates the variables used in this research and the equations required to get them. Based on the above analysis, the following models are employed:

\section{Model 1}

$\mathrm{ROA}=\beta_{0}+\beta_{1} \mathrm{LEV}+\beta_{2}(\mathrm{TOA})+\beta_{3} \mathrm{LIQ}+\beta_{4}(\mathrm{UR})+\beta_{5}(\mathrm{SM})+\beta_{6}(\mathrm{SZE})+\varepsilon$

\section{Model 2}

$\mathrm{ROE}=\beta_{0}+\beta_{1} \mathrm{LEV}+\beta_{2}(\mathrm{TOA})+\beta_{3} \mathrm{LIQ}+\beta_{4}(\mathrm{UR})+\beta_{5}(\mathrm{SM})+\beta_{6}(\mathrm{SZE})+\varepsilon$

\section{Empirical Results}

Table 1 Descriptive Statistics: - Variables of Analysis

\begin{tabular}{|c|c|c|c|c|c|}
\hline Variable & Range & Mean & Std. Deviation & Skewness & Kurtosis \\
\hline $\begin{array}{ll}\text { Return } & \text { on } \\
\text { Assets } & \end{array}$ & .464161 & .06564744 & .051049008 & 2.265 & 16.131 \\
\hline $\begin{array}{l}\text { Return on } \\
\text { Equity }\end{array}$ & 16.694463 & .26979842 & 1.143600508 & 14.113 & 203.434 \\
\hline Leverage & 2.362699 & .60045336 & .387007066 & 1.581 & 6.575 \\
\hline $\begin{array}{l}\text { Tangibility } \\
\text { of assets }\end{array}$ & .210182 & .03699655 & .042904050 & 1.934 & 4.206 \\
\hline Liquidity & 31.362432 & 1.72897923 & 2.703121971 & 7.675 & 73.666 \\
\hline $\begin{array}{l}\text { Underwriting } \\
\text { risk }\end{array}$ & 457.293333 & 2.70947312 & 31.301772343 & 14.584 & 212.799 \\
\hline $\begin{array}{l}\text { Solvency } \\
\text { margin }\end{array}$ & $\begin{array}{l}2492.36638 \\
5\end{array}$ & 24.05074553 & $\begin{array}{l}176.48002314 \\
3\end{array}$ & 13.099 & 182.733 \\
\hline $\begin{array}{l}\text { Company } \\
\text { size }\end{array}$ & 17.289159 & 11.29466410 & 4.366055102 & $-2.008-$ & 2.739 \\
\hline
\end{tabular}

Source: Authors' calculations based on SPSS software package

Table 1: shows the descriptive statistics for all the variables used in the research based on 213 observations of all the 22 Egyptian non-life insurance companies operating in the market. It may be noted that the return on assets, the return on equity, the leverage ratio, tangibility of assets, liquidity, underwriting risk, solvency margin and company size all have a positive mean. ROA averaged 0.06565 and ranged from 0 to 0.4642 . ROE averaged 0.26980 and ranged from 0 to 16.69 .The leverage averaged 0.60045 and 
ranged from 0 to 2.36 . The tangibility of assets averaged .03700 and ranged from 0 to 0.2102 . The liquidity averaged 1.73 and ranged from 0 to 31.36. The underwriting risk averaged 2.71 and ranged from 0 to 457.29. The solvency margin averaged 24.05 and ranged from 0 to 2492.37. The company size averaged 11.29 and ranged from 0 to 17.29 . The descriptive statistics implied that nonexistence of variation in ROA and ROE since the standard deviation statistics for ROA (5\%) and ROE (114\%) were below the respective means (6\% and $26 \%)$.

Table 2 One-Sample Kolmogorov-Smirnov Test

\begin{tabular}{|ll|l|l|l|l|l|l|l|l|}
\hline & & ROA & ROE & LEV & TOA & LIQ & UR & SM & SZE \\
\hline $\mathrm{N}$ & & 213 & 213 & 213 & 213 & 213 & 213 & 213 & 213 \\
& Absolute & .099 & .407 & .199 & .194 & .323 & .486 & .470 & .330 \\
Most Extreme Differences & Positive & .069 & .407 & .199 & .150 & .323 & .486 & .470 & .203 \\
& Negative & $-.099-$ & $-.407-$ & $-.147-$ & $-.194-$ & $-.261-$ & $-.466-$ & $-.446-$ & $-.330-$ \\
Kolmogorov-Smirnov Z & & 1.448 & 5.947 & 2.899 & 2.835 & 4.718 & 7.095 & 6.857 & 4.815 \\
Sig. (2-tailed) & & .030 & .000 & .000 & .000 & .000 & .000 & .000 & .000 \\
\hline
\end{tabular}

Source: Authors' calculations based on SPSS software package

Table 2: shows Kolmogorov-Smirnov Test for all the variables used in the research based on 213 observations of all the 22 Egyptian non-life insurance companies operating in the market. Moreover, it may be noted that reveals not normally distributed across the all variables during the period from 2008 to 2017 ("sig."<0.05).

Figure 2 Scatterplot of Return on Assets and Return on Equity
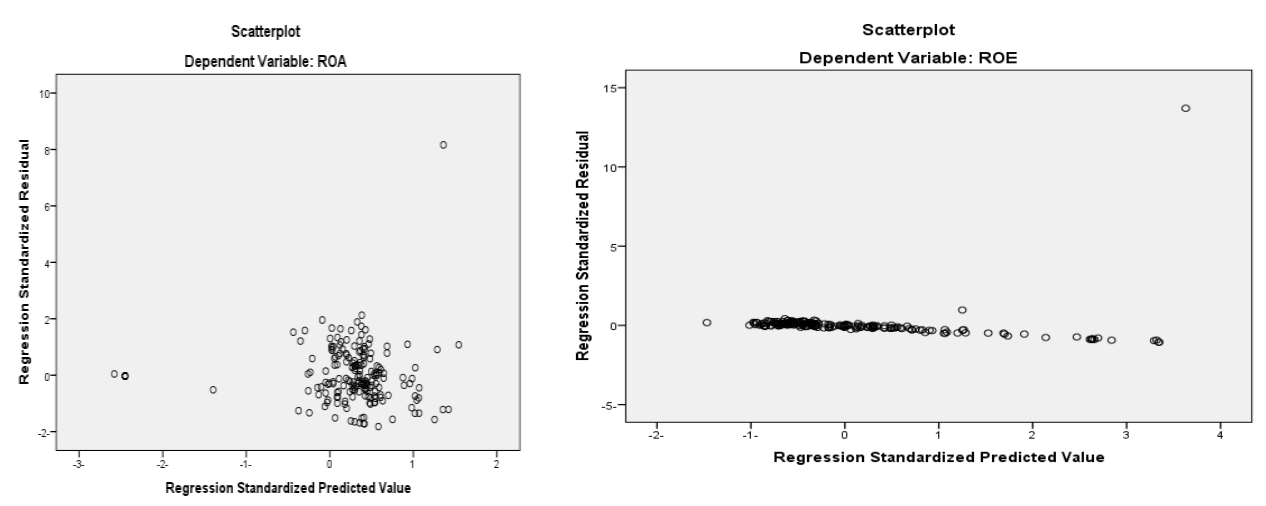

\begin{tabular}{|l|l|l|l|l|l|l|l|l|}
\hline & ROA & ROE & LEV & TOA & LIQ & UR & SM & SZE \\
\hline ROA & 1.000 & 0.693 & 0.157 & 0.256 & 0.458 & 0.100 & 0.452 & 0.453 \\
Sig. (2-tailed) & & 0.000 & 0.022 & 0.000 & 0.000 & 0.145 & 0.000 & 0.000 \\
\hline ROE & & 1.000 & 0.484 & 0.111 & 0.137 & 0.274 & 0.178 & 0.620 \\
Sig. (2-tailed) & & & 0.000 & 0.105 & 0.046 & 0.000 & 0.009 & 0.000 \\
\hline LEV & & & 1.000 & 0.294 & -0.296 & 0.469 & -0.248 & 0.518 \\
\hline
\end{tabular}




\begin{tabular}{|c|c|c|c|c|c|}
\hline Sig. (2-tailed) & 0.000 & 0.000 & 0.000 & 0.000 & 0.000 \\
\hline $\begin{array}{l}\text { TOA } \\
\text { Sig. (2-tailed) }\end{array}$ & 1.000 & $\begin{array}{l}0.294 \\
0.000\end{array}$ & $\begin{array}{l}0.408 \\
0.000\end{array}$ & $\begin{array}{l}0.213 \\
0.002\end{array}$ & $\begin{array}{l}0.085 \\
0.217\end{array}$ \\
\hline $\begin{array}{l}\text { LIQ } \\
\text { Sig. (2-tailed) }\end{array}$ & & 1.000 & $\begin{array}{l}0.193 \\
0.005 \\
\end{array}$ & $\begin{array}{l}0.804 \\
0.000\end{array}$ & $\begin{array}{l}0.143 \\
0.037\end{array}$ \\
\hline $\begin{array}{l}\text { UR } \\
\text { Sig. (2-tailed) }\end{array}$ & & & 1.000 & $\begin{array}{l}0.165 \\
0.016 \\
\end{array}$ & $\begin{array}{l}0.352 \\
0.000\end{array}$ \\
\hline $\begin{array}{l}\text { SM } \\
\text { Sig. (2-tailed) }\end{array}$ & & & & 1.000 & $\begin{array}{l}0.356 \\
0.000\end{array}$ \\
\hline $\begin{array}{l}\text { SZE } \\
\text { Sig. (2-tailed) }\end{array}$ & & & & & 1.000 \\
\hline
\end{tabular}

Table 3: correlation between selected variables

Source: Authors' calculations based on SPSS software package

Table 3: shows that leverage, tangibility of assets, liquidity, underwriting risk, solvency margin and company size are positively correlated with the profitability which measured by ROA and ROE. Also, there is a significant positive relationship between all independent variables and profitability except underwriting risk. Furthermore, the table shows that both liquidity and solvency margin ratios are negatively correlated with leverage. The analysis also indicates that there is a significant positive relationship between company size and tangibility of assets.

Figure 3 Histogram of Return on Assets and return on Equity
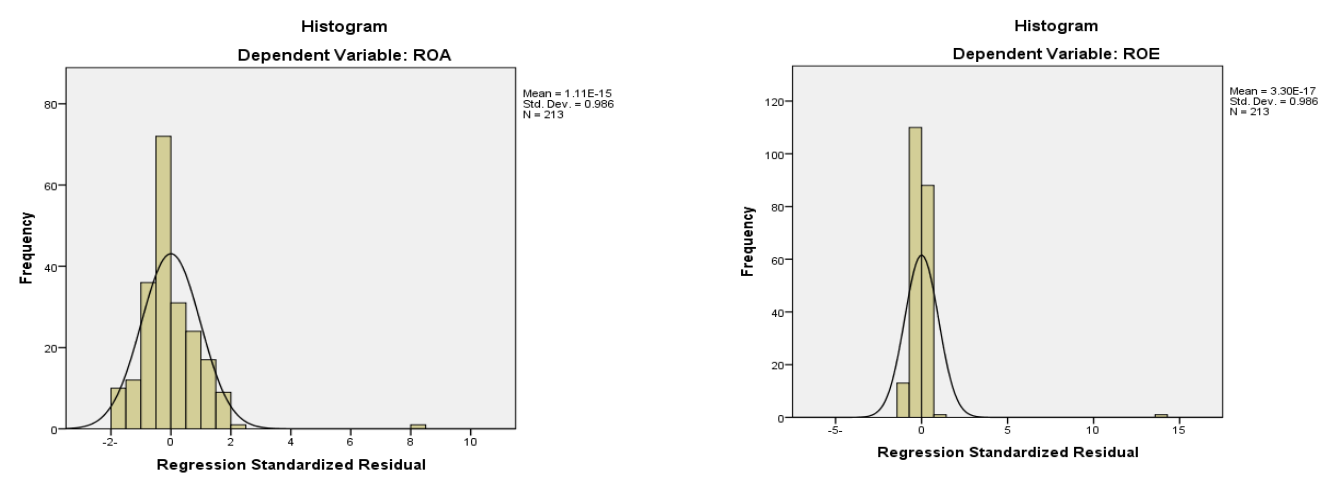

Figure 4 Normal P - P Plot of regression Standardized Residual 
(Return on Assets and return on Equity)
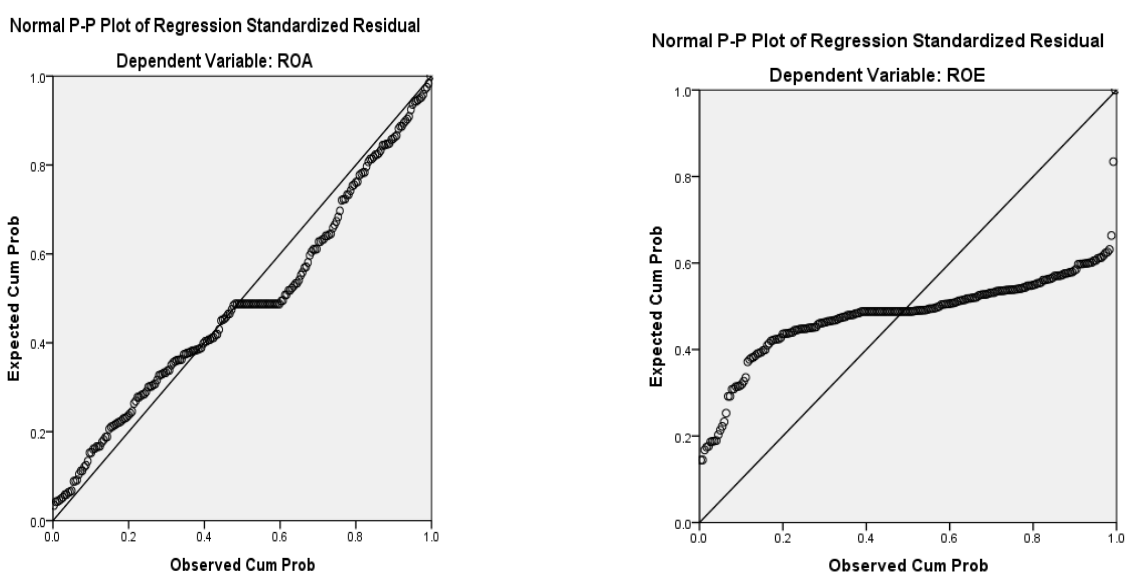

Table 4: ANOVA for ROA

\begin{tabular}{|ll|l|l|l|l|l|}
\hline \multicolumn{2}{|c|}{ Model } & Sum of Squares & df & Mean Square & F & Sig. \\
\hline \multirow{4}{*}{1} & Regression & .145 & 6 & .024 & 12.266 & .000 \\
& Residual & .407 & 206 & .002 & & \\
& Total & .552 & 212 & & & \\
\hline
\end{tabular}

Source: Authors' calculations based on SPSS software package

Table (4) shows the extent to which the first linear model interprets the data. $\mathrm{F}$-value $=12.266$ indicates that the linear regression model explains a large part of the data and that the random variations are few. The importance of Ftest is highlighted when the model has more than one independent variable. In this case, $\mathrm{F}$ - test examines all the parameters of the model.

$\mathrm{H}_{0}: \beta_{1}=0 ; \beta_{2}=0 ; \ldots \ldots ; \beta_{\mathrm{k}}=0$

$\mathrm{H}_{1}: \beta_{1} \neq 0 ; \beta_{2} \neq 0 ; \ldots \ldots ; \beta_{\mathrm{k}} \neq 0$

In case of rejection of the null hypothesis, we proceed to test the parameters of the model so that the significance of each parameter of the model is tested separately from the other

It is also possible to calculate the coefficient of determination which is equal

$\mathrm{R}^{2}=\frac{S S R}{S S T}=\frac{0.145}{0.552}=0.263$

Thus, the model interprets $26.3 \%$ of the differences in the values of the dependent variable, while $73.7 \%$ of the differences are due to random factors. To find out the extent of random error dispersion around the 
regression line, use the average sum of squares of variance for the Residuals, which is equal to:

$\mathrm{MSE}=\frac{0.407}{206}=0.00198$

MSE $=0.00198$ small value refers to the concentration of data around the regression line, but we should not neglect the effect of large dependent variable values on random error variation.

Table 5: Coefficients for ROA

\begin{tabular}{|c|c|c|c|c|c|c|}
\hline \multirow{2}{*}{\multicolumn{2}{|c|}{ Model }} & \multicolumn{2}{|c|}{ Unstandardized Coefficients } & Standardized & \multirow[t]{2}{*}{$t$} & \multirow[t]{2}{*}{ Sig. } \\
\hline & & $B$ & Std. Error & Beta & & \\
\hline \multirow{7}{*}{1} & (Constant) & .001 & .009 & & .163 & .870 \\
\hline & LEV & .023 & .010 & .172 & 2.182 & .030 \\
\hline & TOA & $-.031-$ & .075 & $-.026-$ & $-.410-$ & .682 \\
\hline & LIQ & .001 & .001 & .051 & .771 & .442 \\
\hline & UR & .000 & .000 & $-.082-$ & $-1.306-$ & .193 \\
\hline & SM & $-1.643 E-005$ & .000 & $-.057-$ & $-.918-$ & .360 \\
\hline & SZE & .005 & .001 & .385 & 4.974 & .000 \\
\hline
\end{tabular}

Source: Authors' calculations based on SPSS software package

The previous table estimates of the parameters of the model with $t$ tests for the significance of the model parameters, where $\left(\beta_{0}=0.001, \beta_{1}=0.023, \beta_{2}=\right.$ -0.031 ,

$\left.\beta_{3}=0.001, \beta_{4}=0.000, \beta_{5}=-0.0000164, \beta_{6}=0.005\right)$

Accordingly, the estimated model is

$\mathrm{ROA}=0.001+0.023 x_{1}-0.031 x_{2}+0.001 x_{3}+0.000 x_{4}-0.0000164 x_{5}+$ $0.005 x_{6}$

Table 6: Collinearity Diagnostics for ROA

\begin{tabular}{|ll|l|l|l|l|l|l|l|l|l|}
\hline Model & Dimension & Eigenvalue & Condition Index & \multicolumn{4}{|l|}{ Variance Proportions } \\
\cline { 5 - 10 } & & & & (Constant) & LEV & TOA & LIQ & UR & SM & SZE \\
\hline & 1 & 3.715 & 1.000 & .01 & .01 & .02 & .02 & .00 & .00 & .01 \\
& 2 & 1.211 & 1.751 & .00 & .01 & .01 & .06 & .37 & .22 & .00 \\
1 & 3 & .903 & 2.029 & .00 & .00 & .00 & .02 & .29 & .69 & .00 \\
& 4 & .552 & 2.594 & .00 & .02 & .05 & .70 & .34 & .03 & .00 \\
& 5 & .428 & 2.947 & .02 & .03 & .91 & .02 & .00 & .01 & .01 \\
& 5 & .140 & 5.159 & .41 & .61 & .01 & .11 & .00 & .03 & .01 \\
& 6 & .052 & 8.419 & .56 & .32 & .00 & .06 & .00 & .03 & .98 \\
\hline
\end{tabular}

Source: Authors' calculations based on SPSS software package

The previous table represents calculations related to the matrix of variables; the problem of multiple linear regression is shown if the condition index is large ( condition index greater than 15) 
The Effect of Company Specific Factors on the Profitability of Property \& Casualty Insurance industry in Egypt ..... Dr. Mahmoud Elsayed

Table 7: ANOVA for ROE

\begin{tabular}{|ll|l|l|l|l|l|}
\hline Model & & Sum of Squares & df & Mean Square & F & Sig. \\
\hline \multirow{3}{*}{2} & Regression & 16.188 & 6 & 2.698 & 2.129 & .051 \\
& Residual & 261.070 & 206 & 1.267 & & \\
& Total & 277.258 & 212 & & & \\
\hline
\end{tabular}

Source: Authors' calculations based on SPSS software package

Table ANOVA shows the extent to which the second linear model interprets the data. F-value $=2.129$ indicates that the linear regression model explains a large part of the data and that the random variations are few. The importance of F- test is highlighted when the model has more than one independent variable. In this case, F- test examines all the parameters of the model

$\mathrm{H}_{0}: \beta_{1}=0 ; \beta_{2}=0 ; \ldots \ldots ; \beta_{\mathrm{k}}=0$

$\mathrm{H}_{1}: \beta_{1} \neq 0 ; \beta_{2} \neq 0 ; \ldots \ldots ; \beta_{\mathrm{k}} \neq 0$

In case of rejection of the null hypothesis, we proceed to test the parameters of the model so that the significance of each parameter of the model is tested separately from the other

It is also possible to calculate the coefficient of determination which is equal $\mathrm{R}^{2}=\frac{S S R}{S S T}=\frac{16.188}{277.258}=0.058$

Thus, the model interprets $5.8 \%$ of the differences in the values of the dependent variable, while $94.2 \%$ of the differences are due to random factors. To find out the extent of random error dispersion around the regression line, use the average sum of squares of variance for the Residuals, which is equal to:

MSE $=\frac{261.070}{206}=1.2673$

MSE $=1.2673$ small value refers to the concentration of data around the regression line, but we should not neglect the effect of large dependent variable values on random error variation.

Table 8: Coefficients for ROE

\begin{tabular}{|ll|l|l|l|l|l|}
\hline \multicolumn{2}{|l|}{ Model } & \multicolumn{2}{|l|}{ Unstandardized Coefficients } & $\begin{array}{l}\text { Standardized } \\
\text { Coefficients }\end{array}$ & t & Sig. \\
\cline { 3 - 5 } & & $\mathrm{B}$ & Std. Error & Beta & & \\
\hline \multirow{2}{*}{2} & (Constant) & .034 & .216 & & .157 & .875 \\
& LEV & .204 & .263 & .069 & .776 & .439 \\
\hline
\end{tabular}




\begin{tabular}{|l|l|l|l|l|l|}
\hline TOA & 5.901 & 1.895 & .221 & 3.113 & .002 \\
LIQ & $-.010-$ & .032 & $-.025-$ & $-.329-$ & .742 \\
UR & .000 & .003 & .004 & .059 & .953 \\
SM & $4.400 \mathrm{E}-005$ & .000 & .007 & .097 & .923 \\
SZE & $-.008-$ & .023 & $-.030-$ & $-.342-$ & .733 \\
\hline
\end{tabular}

Source: Authors' calculations based on SPSS software package

The previous table estimates of the parameters of the model with $t$ tests for the significance of the model parameters, where $\left(\beta_{0}=0.034, \beta_{1}=0.204, \beta_{2}=\right.$ 5.901,

$\left.\beta_{3}=-0.010, \beta_{4}=0.000, \beta_{5}=0.000044, \beta_{6}=-0.008\right)$

Accordingly, the estimated model is

$\mathrm{ROE}=0.034+0.204 x_{1}+5.901 x_{2}-0.010 x_{3}+0.000 x_{4}+0.000044 x_{5}+$ $0.008 x_{6}$

Table 9: Collinearity Diagnostics for ROE

\begin{tabular}{|c|c|c|c|c|c|c|c|c|c|c|}
\hline \multirow[t]{2}{*}{ Model } & \multirow[t]{2}{*}{ Dimension } & \multirow[t]{2}{*}{ Eigenvalue } & \multirow{2}{*}{$\begin{array}{l}\text { Condition } \\
\text { Index }\end{array}$} & \multicolumn{7}{|c|}{ Variance Proportions } \\
\hline & & & & (Constant) & LEV & TOA & LIQ & UR & SM & SZE \\
\hline \multirow{7}{*}{2} & 1 & 3.715 & 1.000 & .01 & .01 & .02 & .02 & .00 & .00 & .01 \\
\hline & 2 & 1.211 & 1.751 & .00 & .01 & .01 & .06 & .37 & .22 & .00 \\
\hline & 3 & .903 & 2.029 & .00 & .00 & .00 & .02 & .29 & .69 & .00 \\
\hline & 4 & .552 & 2.594 & .00 & .02 & .05 & .70 & .34 & .03 & .00 \\
\hline & 5 & .428 & 2.947 & .02 & .03 & .91 & .02 & .00 & .01 & .01 \\
\hline & 6 & .140 & 5.159 & .41 & .61 & .01 & .11 & .00 & .03 & .01 \\
\hline & 7 & .052 & 8.419 & .56 & .32 & .00 & .06 & .00 & .03 & .98 \\
\hline
\end{tabular}

Source: Authors' calculations based on SPSS software package

\section{Conclusion}

This paper identified the internal variables that affect profitability of non-life Egyptian insurance market measured by ROA and ROE. A multiple regression technique has been performed by considering ROA and ROE as dependent variables and leverage, tangibility of assets, liquidity, underwriting risk, solvency margin and company size as independent variables. The results for these analysis show that the most important variables that affect the performance of the insurance companies are leverage, company size, underwriting risk, solvency margin and liquidity on both models. Whereas underwriting risk has insignificant effect on ROA, on the other hand, underwriting risk has significant effect on ROE. Liquidity 
has a negative effect on leverage and solvency margin. Also, there is a positive relationship between company size and ROA. Solvency margin has a positive significant effect on the profitability for Egyptian insurance market. In addition, the adverse and statistical relationship between solvency margin and leverage is important.

\section{References}

1. Abeyrathna, S.,\& Priyadarshana, A.(2019). Impact of Firm size on Profitability (Special reference to listed manufacturing companies in Sri Lanka). International Journal of Scientific and Research Publications, 9(6), 561-564.

2. Aburime, T. (2008). Determinant of Bank Profitability: Company Level Evidence from Nigeria. Working Paper, Department of Banking and Finance, University of Nigeria.

3. Ana ,k. ,\& Dusan,D. (2016). The determinants of Serbian banking industry profitability. Economic Research-Ekonomska Istraživanja, 29(1), 459-474.

4. Ana-Maria, B., \& Ghiorghe, B. (2014).The Determinants of Financial Performance in the in the Romanian Insurance. International Journal of Academic Research in Accounting, Finance and Management Sciences, 4(1), 299-308.

5. Aster,K.,\& Meseret,T. (2019). Determinants of Financial Performance; Evidence from Ethiopia Insurance Companies. Journal of Accounting, Finance and Auditing Studies 5(1) 155-172. 
6. Athanasoglous P., Brissimis,N.,\& Delis,D. (2005). Bank-Specific, Industry- Specific and Macroeconomic Determinants of Bank Profitability. Bank of Greece, Working Paper, 25, 1-35.

7. Bilal, J., Khan S.,\&Tufail S. (2013). Determinants Of profitability panel data evidence from insurance Sector of Pakistan. Elixir Finance Management Journal, 57(A ), 14377-14382.

8. Charumathi, B. (2012). On the Determinants of Profitability of Indian Life Insurers - An Empirical Study. Proceedings of the World Congress on Engineering, I ,London, U.K. 5.

9. Chen-Ying, L. (2014). The effects of firm specific Factors and macroeconomics on profitability of Property-liability insurance industry in Taiwan. Asian Economic and Financial Review, 4( 5), 681-691.

10. Daniel, M., \& Tilahun, A. (2013). Firm Specific factors that determine insurance Companies' performance in Ethiopia. European Scientific Journal, 9(10) , 245-255.

11. Emine,k. (2015).The Effects of Firm-Specific Factors on the Profitability of Non-Life Insurance Companies in Turkey. International Journal of Financial Studies, 3, 510-529.

12. Eric,k.,Samuel ,A.,\& Victor,C. (2013).Determinants Of Profitability Of Insurance Firms In Ghana . International Journal of Business and Social Research (IJBSR), 3(3), 43-50.

13. Hamadan ,A. (2008). Determinats of insurance companies' profitability in UAE.Universiti Utara, Malasiya.Phd thesis.

14. Hifza, M. (2011). Determinants of insurance Companies' profitability: An analysis of insurance Sector of Pakistan. Academic Research International , 1( 3) , 315-321.

15. Kaukab ,A.,\& Nawaz,A.(2019).Relationship Between Firm Size and Profitability : Investigation From Textile Sector of Pakistan. International Journal of Information, Business and Management, 11(2), 62-73.

16. Okparaka,V. (2018).Contribution Of Intra-Industry Variables On Profitability Of Insurance Business In Nigeria. Journal on Banking Financial Services \& Insurance Research, 8(2), 1-23.

17. Shahid,J., Khurshed,I. ,\& Sham ,R.(2014).Determinants of Profitability of Islamic and conventional Insurance Companies in Pakistan: an Internal Evaluation. Abasyn Journal of Social Sciences, 7(1), 57-63. 
The Effect of Company Specific Factors on the Profitability of Property \& Casualty Insurance industry in Egypt ..... Dr. Mahmoud Elsayed

18. Teklit,A.,\& Jasmindeep,K. (2017).Determinants of insurance companies' profitability Analysis of insurance sector in Ethiopia. International Journal of Research in Finance and Marketing (IJRFM), 7(4), 124-137. 